\title{
REVISION KNEE REPLACEMENT SURGERY AFTER TWO FAILED REPLACEMENTS
}

\section{Dhillon H.S. ', ${ }^{2}$, Serova N.S. ', Lichagin A.V.'}

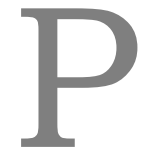

urpose. Purpose of the study is to have a detailed examination and investigation of 1 . the patient with all the required parameters.

- Sechenov University.

Material and methods. Revision knee replacement prosthesis making a difference Moscow, Russia.

in treatment outcome. Centre.

Results. The result after the sleeve operation was uneventful and the patient had no Al Shahba, Sharjah, UAE. complaints or pain even after a year of surgery.

Conclusion. Long term complications are comparatively less when a proper prosthesis is selected for the particular patient operation

Keywords: severe knee osteoarthritis, chronic knee pain, implant loosening, wedge $\&$ rod treatment, sleeve reconstruction.

Corresponding author: Dhillon H.S., e-mail: harmeetsingh333@mail.ru

For citation: Dhillon H.S., Serova N.S., Lichagin A.V. Revision knee replacement surgery after two failed replacements. REJR 2018; 8(2):242-246. DOI:10.21569/2222-7415-2018-82-242-246.

Статья получена: $\quad 09.02 .2018 \quad$ Статья принята: $\quad$ 06.03.2018

\section{РЕВИЗИОННАЯ ОПЕРАЦИЯ ПО ЗАМЕНЕ КОАЕННОГО СУСТАВА ПОСАЕ АВУХ НЕУААЧНЫХ ПОПЫТОК ЭНАОПРОТЕЗИРОВАНИЯ}

\author{
Аилмон Х.С. ${ }^{1,2}$, Серова Н.С. ${ }^{1}$, Аычагин А.В. ${ }^{1}$
}

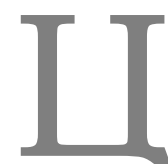

ель исследования. Провести детальный осмотр и исследование пациента после проведения замены коленного сустава.

Материал и методы. Результаты мечения напрямую зависят от ревизионной операции по замене коленного сустава.

Результаты. Результат после установки гильзы протеза был удовцетворительным. У пациента не возникало жалоб или боли даже через год после операции.

Вывод. При выборе правильного протеза для замены коленного сустава поздние постоперационные осложнения встречаются реже.

Ключевые слова: тяжелый остеоартрит коленного сустава, хроническая боль в комене, ослабление имплантата, цечение клином и стержнем, реконструкция принимающей гимьзы импланта.

Контактный автор: Dhillon H.S., e-mail: harmeetsingh333@mail.ru

Для иитирования: Dhillon H.S., Serova N.S., Lichagin A.V. Revision knee replacement surgery after two failed replacements. REJR 2018; 8(2):242-246. DOI:10.21569/22227415-2018-8-2-242-246.

Received: $\quad$ 09.02.2018 Accepted: 06.03.2018

1 - ФГАОУ ВО Первый МГМУ имени И.М. Сеченова (Сеченовский Университет). г. Москва, Россия. 2 - Медицинский Центр доктора Санни, А^ь Шахба, Шарджа, ОАЭ. 
I ntroduction.

The average life of an artificial knee or hip joint is anywhere between 15 to 25 years. This depends on quality of bone in which the parts are fixed, the quality of surgery, and complication like injury or infection in the implanted joint.The surgery of revision is more demanding than the first surgery, because in revision scenario, the quality of the bone is usually poor, with large gaps that may need filling up. Also the ligaments may be damaged beyond repair, requiring specialized implants.

Purpose of the study.

Purpose of the study is to have a detailed examination and investigation of the patient with all the required parameters so as to have the best treatment option with minimal or no postoperative complications.

\section{Case study.}

An elderly 72 years lady had Severe left knee osteoarthritis followed by left sided primary knee replacement done in October 2014 using simple implant (as in figure 1) in India (bengaluru) but still complained of pain till 9-12 months after the operation.

Before case presentation, following are specialized implants and their use in various special situations is explained in the case study.

1. Rods:When the bone needs additional support, one may use long rods. As in case of fracture in the tibia that needs additional support

2. Wedges or augments: when the bone on one side is more damaged, one may need wedge or augment to support the defect

3. Sleeve or cone: when there is big defect in the bone, one may need a sleeve or cone to fill it up

4. Rotatinghinge:a special kind of joint that is needed when ligaments can no longer support the regular implant.

There was Implant Loosening (as in fig. 1) and hence the same surgeon surgeon used wedge and rod (fig. 2) to fill up the bone defect

Unfortunately the "wedge and rod treatment" FAILED for the patient,

Then the patient came to our NMC hospital in Dubai in April 2017, on detailed investigation we found that her upper tibial bone was completely missing (as in figure 3,4 )

Our surgeon opted for SLEEVE RECONSTRUCTION which is ideal for such a massive bone loss; X-rays after sleeve reconstruction and complete stabilization of joint is absolutely normal with no complaints (as in figure 5) from the patient since the last one year.

\section{Results.}

The result after the sleeve operation was uneventful and the patient had no complaints or pain even after a year of surgery.

\section{Conclusion.}

Long term complications are comparatively less when a proper prosthesis is selected for the particular patient operation, with a striking difference in chronic knee pain according to my study..

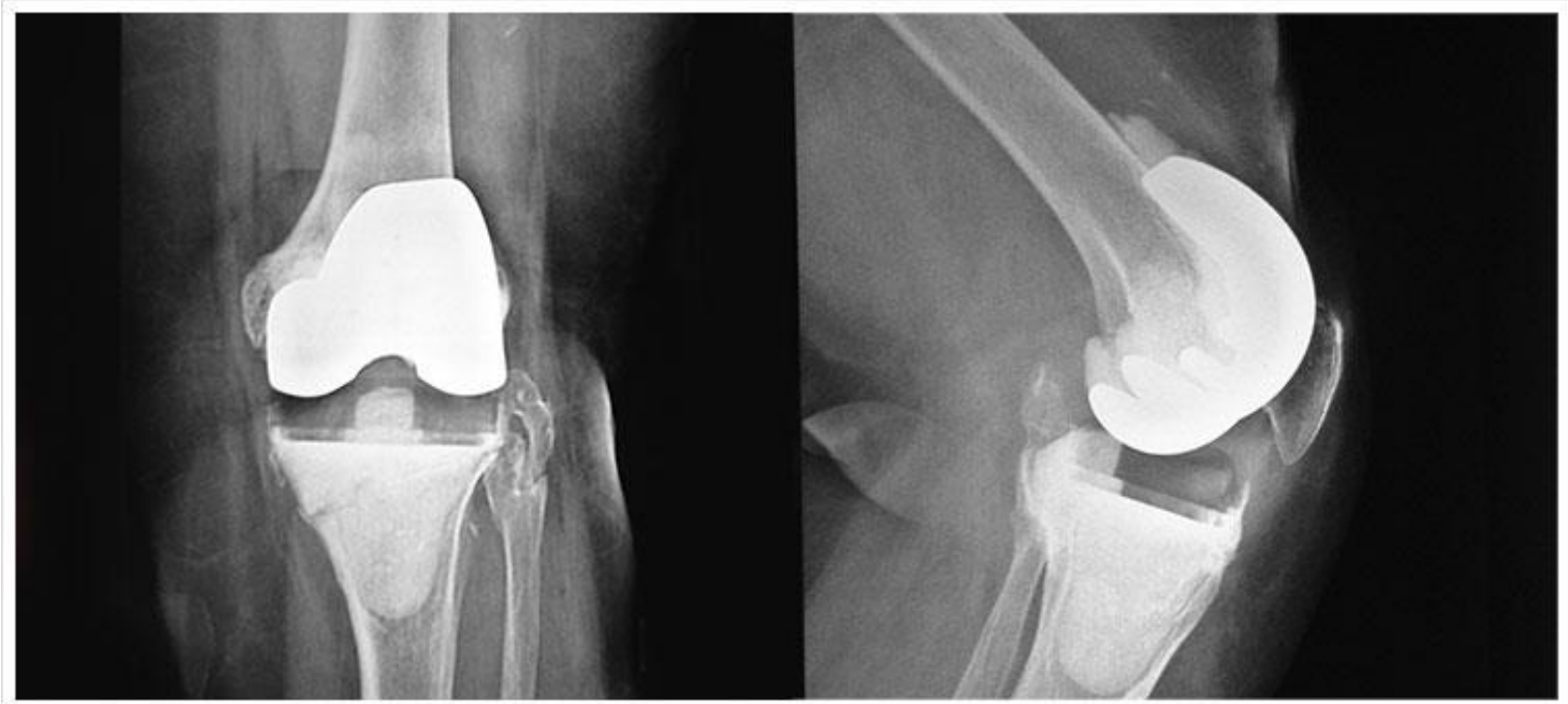

Fig. 1 (Рис. 1 )

Fig. 1. X-ray.

Left sided total knee replacement prosthesis, however mild "implant loosening" noted after 6 months.

Рис. 1. Рентгенограммы коленного сустава, прямая и боковая проекции.

Тотальное эндопротезирование мевого коленного сустава. Через 6 месяцев отмечается “ослабление имплантата". 


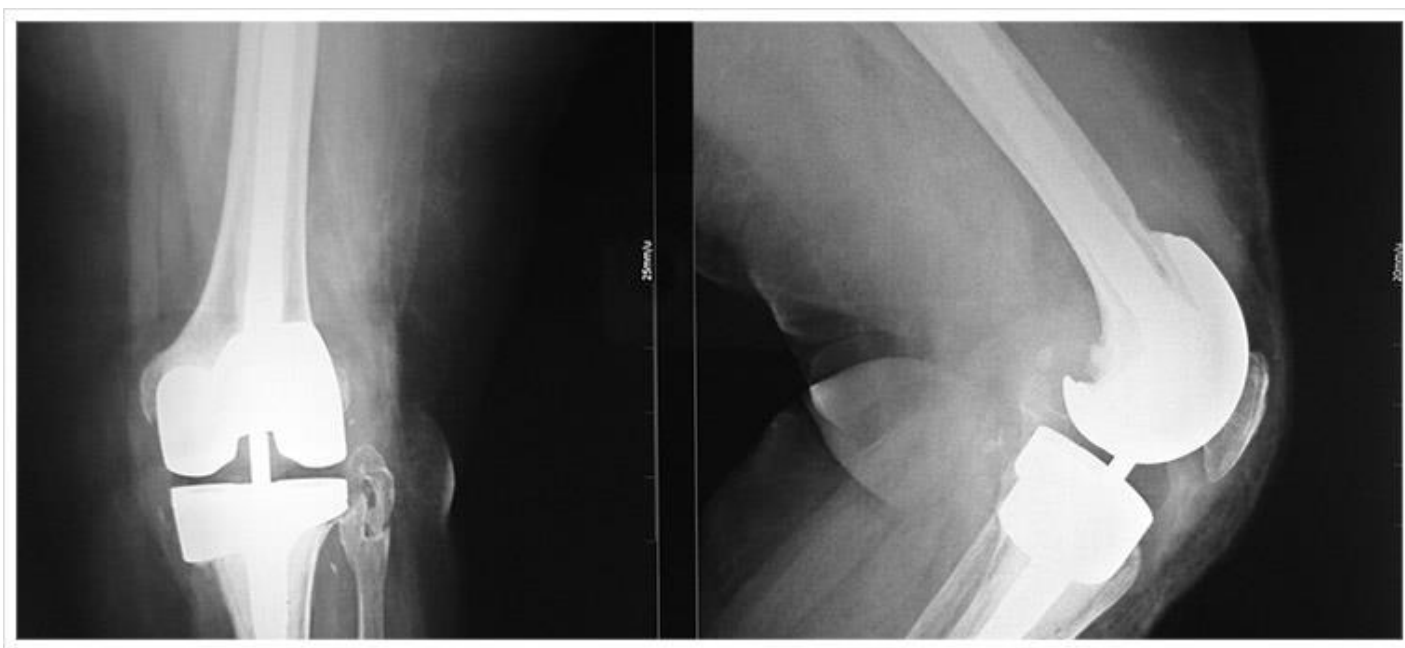

Fig. 2 (Рис. 2)

Fig. 2. X-ray.

X-ray reveals "Wedge and Rod technique" to overcome the complication of first surgery.

Рис. 2. Рентгенограммы коленного сустава, прямая и боковая проекции.

ДАя коррекции осложнений, возникших после первой операции, использована техника «Wedge and Rod".

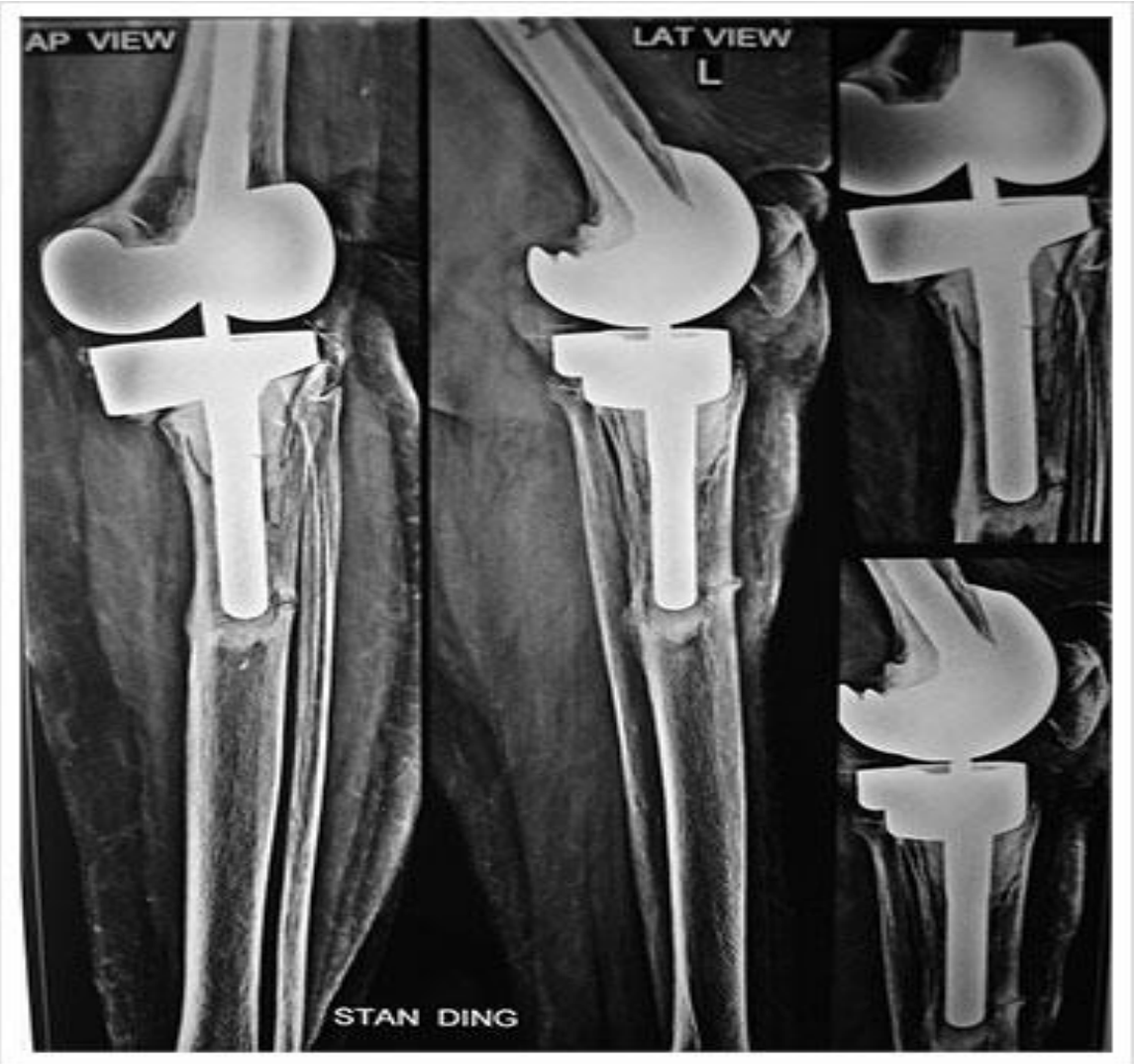

Fig. 3 (Рис. 3)

Fig. 3. X-ray.

$\mathrm{X}$ ray reveals bony defect in proximal tibial aspect.

Рис. 3. Рентгенограммы коленного сустава.

Определяется костный дефект в проксимальном отдеме большеберцовой кости. 


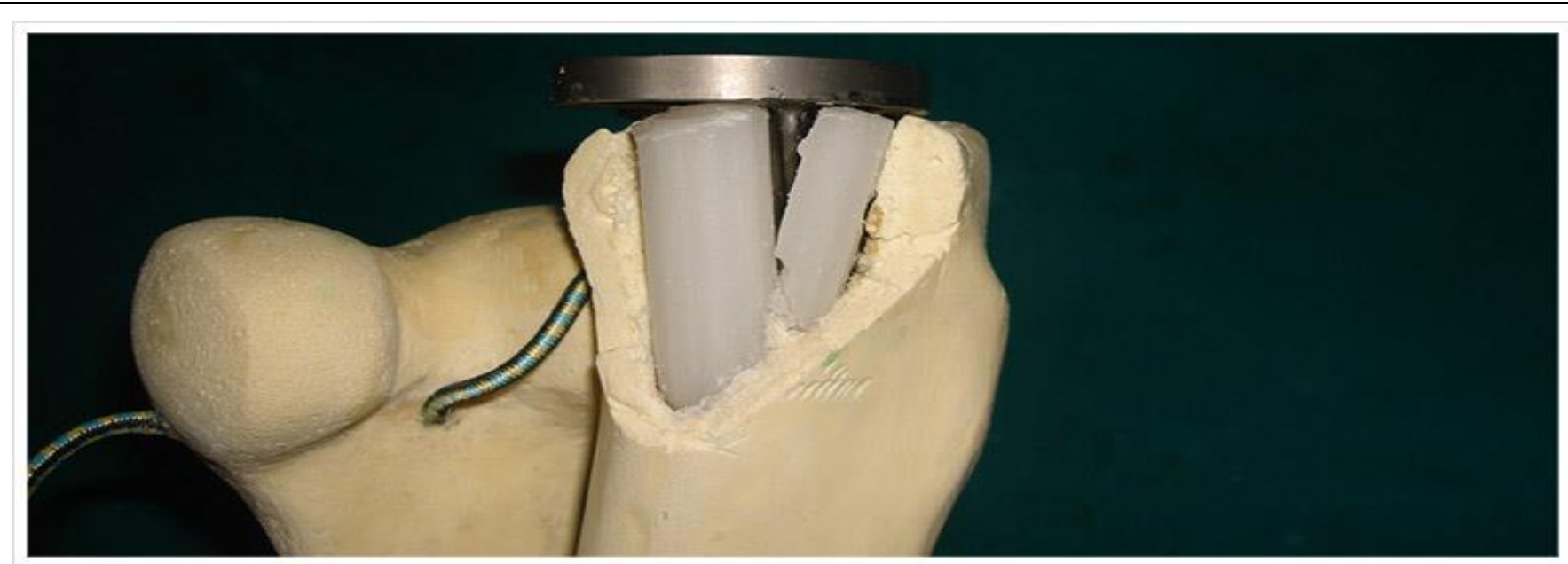

Fig. 4 (Рис. 4)

Fig. 4. 3D reconstruction of the same reveals complete loss of tibial condyle and metaphyses.

Рис. 4. 3D-молель. Отмечается полная потеря большеберцового мыщелка и метафиза.
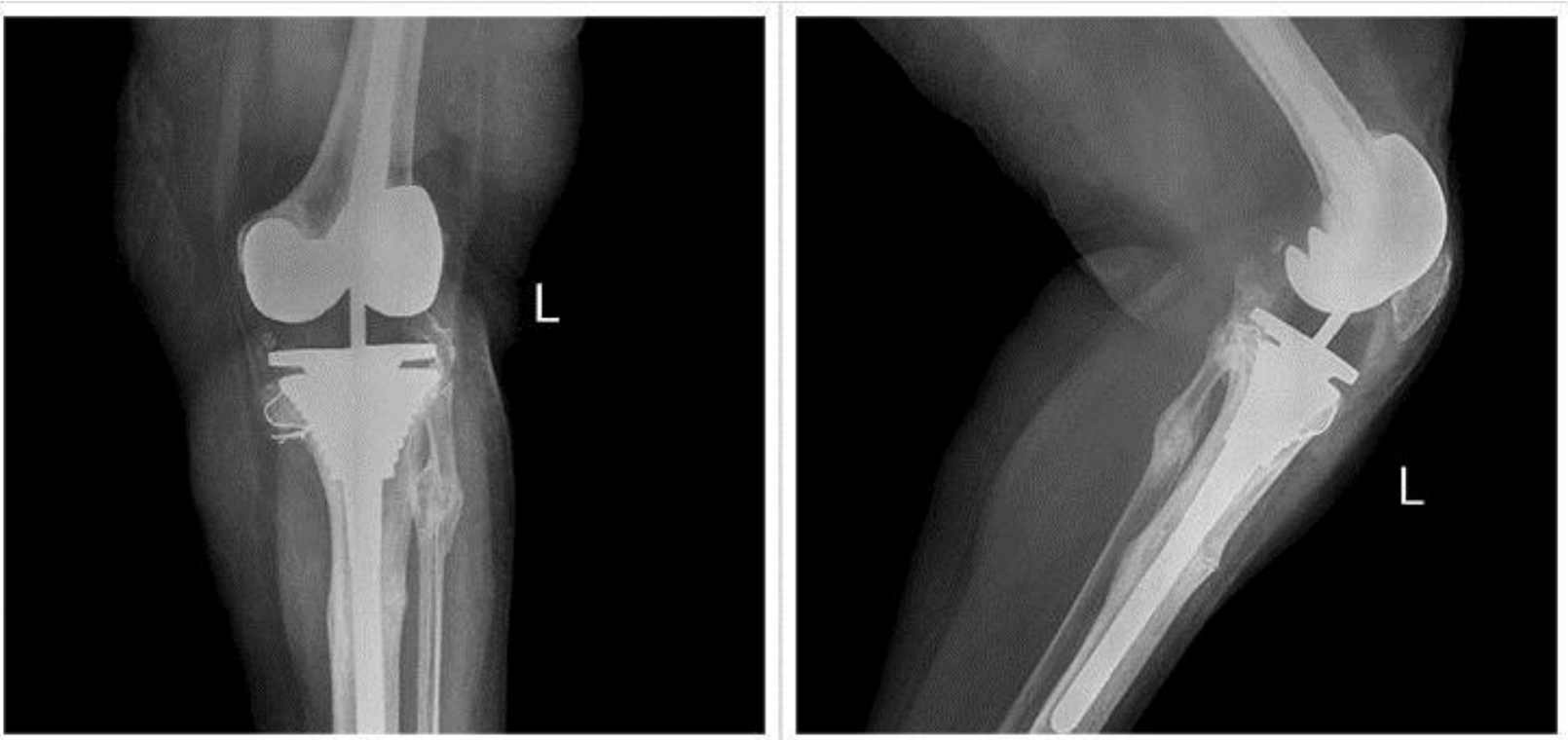

Fig. 5 (Рис. 5)

Fig. 5. X-ray.

$\mathrm{X}$-rays after sleeve reconstruction and complete stabilization of joint.

Рис. 5. Рентгенограммы коленного сустава.

Рентгенограмма принимающей гильзы протеза после реконструкции и признаки полной стабилизации сустава.

Источник финансирования и конфмикт интересов.

Авторы данной статьи подтвердили от-

\section{References:}

1.NIH Consensus Statement on total knee replacement December 8-10, 2003. J Bone Joint Surg Am. 2004; 86-A: 1328-1335. 2.Gill, G.S., Joshi, A.B., Mills, D.M. Total condylar knee arthroplasty. 16- to 21-year results. ClinOrthopRelat Res. 1999; 210- сутствие финансовой поддержки исследования и конфликта интересов, о которых необходимо сообщить.
215.

3.Seah, V.W., Singh, G., Yang, K.Y., Yeo, S.J., Lo, N.N., Seow, K.H. Thirty-day mortality and morbidity after total knee arthroplasty. Ann Acad Med Singapore. 2007; 36: 1010-1012. 


\section{RUSSIAN ELECTRONIC JOURNAL OF RADIOLOGY}

4.Soo Hoo, N.F., Lieberman, J.R., Ko, C.Y., Zingmond, D.S. Factors predicting complication rates following total knee replacement. J Bone Joint Surg Am. 2006; 88: 480-485.

5.Charlson, M.E., Pompei, P., Ales, K.L., MacKenzie, C.R. A new method of classifying prognostic comorbidity in longitudinal studies: development and validation. J Chronic Dis. 1987; 40: 373-383.

6.Katz, J.N., Barrett, J., Mahomed, N.N., Baron, J.A., Wright, R.J., Losina, E. Association between hospital and surgeon procedure volume and the outcomes of total knee replacement. $J$ Bone Joint Surg Am. 2004; 86-A: 1909-1916.

7.Taylor, H.D., Dennis, D.A., Crane, H.S. Relationship between mortality rates and hospital patient volume for Medicare pa- tients undergoing major orthopaedic surgery of the hip, knee, spine, and femur. J Arthroplasty. 1997; 12: 235-242.

8.Jain, N.B., Guller, U., Pietrobon, R., Bond, T.K., Higgins, L.D. Comorbidities increase complication rates in patients having arthroplasty. ClinOrthopRelat Res. 2005; 232-238.

9.Parvizi, J., Mui, A., Purtill, J.J., Sharkey, P.F., Hozack, W.J., Rothman, R.H. Total joint arthroplasty: when do fatal or nearfatal complications occur? J Bone Joint Surg Am. 2007; 89: 2732.

10.Blom, A.W., Brown, J., Taylor, A.H., Pattison, G., Whitehouse, S., Bannister, G.C. Infection after total knee arthroplasty. J Bone Joint Surg Br. 2004; 86: 688-691. 